\title{
AKTIVITAS VOLUME PERDAGANGAN ABNORMAL
}

\author{
ABNORMAL TRADING VOLUME ACTIVITY
}

\author{
Ely Siswanto ${ }^{* 1}$ dan Adi Setiawan*) \\ *) Jurusan Manajemen, Fakultas Ekonomi, Universitas Negeri Malang \\ Jl. Semarang 5, Malang 65145
}

\begin{abstract}
Information content test that aims to see the market reaction to an event only focuses on the presence or the absence of abnormal return. Therefore, it is necessary to test the information content based on trading volume as an alternative to the existing method. This research tried to test information content of bonus share announcements in Indonesia Stock Exchange (BEI). The objectives of this study are to describe the abnormal trading volume activity, test the market reaction to the bonus shares announcements, and determine whether there are differences between ATVA before and after the bonus shares announcements. This research used ATVA analysis method. The sample size used in this research was 33 bonus shares announcement events in BEI in 2006-2017. There was a downtrend of bonus share distribution, and this is because the company considered not to distribute bonus shares at a certain time. Market reacted to bonus share announcement as shown by ATVA in $t_{-1}$ with significance value of 0,048. This reaction indicates a possibility of information leakage regarding bonus share distribution. There is significant difference of ATVA between before and after bonus share announcements with significance value 0,069. There was a decrease in ATVA after the bonus shares announcements. The decrease in ATVA happened due to the investors'strategy to hold their shares until the cumdate period ended.
\end{abstract}

Keywords: abnormal trading volume activity, bonus shares, market reaction, BEI

\begin{abstract}
Abstrak: Pengujian kandungan informasi yang bertujuan untuk melihat reaksi pasar atas suatu peristiwa selama ini hanya berfokus pada ada atau tidaknya abnormal return. Untuk itu diperlukan pengujian kandungan informasi berdasarkan volume perdagangan sebagai alternatif dari metode yang sudah ada. Penelitian ini menguji kandungan informasi dari pengumuman saham bonus di Bursa Efek Indonesia (BEI). Tujuan penelitian ini adalah untuk mendeskripsikan abnormal trading volume activity, menguji reaksi pasar terhadap pengumuman saham bonus, serta untuk mengetahui apakah terdapat perbedaan ATVA sebelum dan sesudah pengumuman saham bonus. Penelitian ini menggunakan analisis ATVA. Besaran sampel yang digunakan dalam penelitian ini adalah sebesar 33 peristiwa pembagian saham bonus di BEI pada periode 2006-2017. Terjadi kecenderungan penurunan jumlah peristiwa pembagian saham bonus, hal ini disebabkan karena perusahaan menganggap tidak perlu membagikan saham bonusnya pada waktu tertentu. Pasar bereaksi pada pengumuman pembagian saham bonus, hal ini ditandai dengan adanya ATVA di $\mathrm{t}_{-1}$ dengan nilai signifikansi sebesar 0,048 . Reaksi ini timbul dari adanya kebocoran informasi mengenai pembagian saham bonus. Terdapat perbedaan ATVA yang signifikan antara sebelum dan sesudah pengumuman saham bonus dengan nilai signifikansi sebesar 0,069. Dimana nilai ATVA di periode setelah pengumuman saham bonus lebih rendah, penurunan ini terjadi karena strategi investor untuk menahan saham yang sudah dimiliki sampai periode cum date berakhir.
\end{abstract}

Kata kunci: abnormal trading volume activity, saham bonus, reaksi pasar, BEI

\footnotetext{
${ }^{1}$ Corresponding author:

Email: ely.siswanto.fe@um.ac.id
} 


\section{PENDAHULUAN}

Volume perdagangan merupakan salah satu indikator yang sering dilaporkan pada berita terkait pasar modal di media massa. Berbeda dengan harga yang selalu menjadi pusat perhatian, volume perdagangan masih kurang dilirik investor dalam mengambil keputusan investasinya. Namun, bukan berarti volume perdagangan merupakan informasi yang tidak dibutuhkan keberadaannya. Blume et al. (1994) dalam Conrad et al. (1994) beranggapan investor yang memasukkan volume perdagangan dalam analisis teknikalnya terbukti lebih baik dalam perdagangan di pasar modal. Selain itu menurut Bajo (2010) volume perdagangan digunakan oleh otoritas perdagangan saham untuk mendeteksi adanya market abuse dan kalangan praktisi menggunakan abnormal volume sebagai sinyal akan datangnya informasi baru.

Volume perdagangan juga kurang mendapat perhatian dari kalangan akademisi jika dibandingkan dengan harga. Hal ini terbukti dari banyaknya model yang lebih berfokus pada return, mulai dari predictability, variability, dan information content (Lo \& Wang, 2000). Selain itu pada asumsi pasar efisien setengah kuat yang diungkapkan Fama (1970) disebutkan bahwa semua informasi yang dipublikasikan tercermin dalam harga saham, sedangkan volume perdagangan tidak memainkan peran apapun dalam asumsi pasar efisien (Bajo, 2010). Bahkan pengujian kandungan informasi yang termasuk dalam event study yang bertujuan melihat reaksi pasar, juga hanya berfokus pada ada atau tidaknya abnormal return seperti yang disampaikan Hartono (2012).

Dibandingkan dengan harga, maka volume perdagangan bisa jadi lebih baik dalam melihat reaksi pasar atas suatu peristiwa atau informasi baru. Bajo (2010) mengungkapkan bahwa volume perdagangan memainkan peran penting dimana dengan harga saja yang tidak mampu untuk mengungkapkan informasi penuh terkait signal news. Selain itu, Beaver (1968) berpendapat bahwa sebuah informasi baru mungkin tidak mampu mengubah ekspektasi pasar secara keseluruhan sehingga tidak ada perubahan harga yang signifikan, namun informasi baru ini mungkin mampu mengubah pandangan investor secara individual sehingga terjadi perubahan volume perdagangan yang signifikan.
Jika benar harga kurang sensitif untuk melihat reaksi pasar, maka diperlukan pengujian kandungan informasi berdasarkan volume perdagangan sebagai basisnya untuk alternatif dari metode yang sudah ada. Oleh karena itu, penelitian ini bertujuan melakukan pengujian kandungan informasi dengan menggunakan volume perdagangan sebagai alternatif dari metode yang sudah ada. Untuk melihat adanya reaksi pasar maka peneliti menggunakan variabel Abnormal Trading Volume Activity (ATVA).

Abnormal Trading Volume Activity (ATVA) merupakan selisih antara Trading Volume Activity yang sesungguhnya terjadi dengan yang diekspektasi oleh investor. Sedangkan Trading Volume Activity itu sendiri adalah rasio antara jumlah lembar saham yang diperdagangkan terhadap jumlah saham yang beredar pada waktu tertentu. Untuk menentukan apakah pasar bereaksi terhadap suatu peristiwa adalah dengan menguji apakah terdapat ATVA yang signifikan di sekitar periode peristiwa.

Penelitian ini menguji kandungan informasi dari pengumuman saham bonus di Bursa Efek Indonesia (BEI). Alasan memilih saham bonus sebagai peristiwa yang diteliti adalah karena pembagian saham bonus yang masih menjadi teka teki bagi para ahli keuangan. Peraturan BAPEPAM No: KEP-35/ $\mathrm{PM} / 2003$, mendefinisi-kan saham bonus adalah saham yang dibagikan secara cuma-cuma kepada pemegang saham berdasarkan jumlah saham yang dimiliki. Akhir akhir ini di Indonesia sendiri pembagian saham bonus semakin jarang dilakukan perusahaan. Terbukti dari data yang diperoleh penulis, selama tahun 2015 dan 2016 tidak terdapat pembagian saham bonus di Bursa Efek Indonesia. Dan pada tahun 2017 hanya terjadi 1 peristiwa pembagian saham bonus. Berbeda dengan beberapa tahun sebelumnya, dimana terdapat 2 peristiwa atau lebih pembagian saham bonus tiap tahunnya.

Sepintas pembagian saham bonus dinilai hanya tindakan pemanis (Ardiansyah, 2012). Bahkan menurut Baker \& Kapoor (2015) pembagian saham bonus jika digambarkan seperti membelah potongan kue menjadi bagian yang lebih kecil lagi. Hal ini karena tidak ada aliran uang ke investor dan tidak mengubah proporsi kepemilikan saham, yang ada jumlah lembar saham yang bertambah. Namun, jika memang tidak berdampak langsung pada perusahaan, kenapa perusahaan mengeluarkan saham bonus? dan kenapa 
pengumuman saham bonus menimbulkan abnormal return yang signifikan di sekitar periode pengumuman seperti yang ditemukan oleh Fernando \& Guneratne (2009), Raja \& Sudhahar (2010), Rohit et al. (2013), Natasya \& Suganda (2013), Ndegwa \& Kiweu (2013), Ahsan et al. (2014), Dewi \& Sukarta (2015), Khurana \& Warne (2016).

Motif dari pembagian saham bonus masih menjadi perdebatan ahli keuangan. Dalam cash subtitution hypothesis dijelaskan bahwa perusahaan mengeluarkan saham bonus sebagai pengganti dividen tunai dalam rangka menjaga cadangan kas perusahaan untuk keperluan lainnya (Ghosh \& Woolridge, 1989). Grinblatt et al. (1984) dengan attention-getting hypothesis berpendapat bahwa manajer melakukan pembagian saham bonus untuk menarik perhatian para analis dan investor. Liquidity hypothesis yang diajukan Lakonishok \& Lev (1987) menyebutkan bahwa manajer perusahaan mengeluarkan saham bonus untuk meningkatkan trading volume dan likuiditas saham mereka dengan menambah jumlah saham yang beredar. Normal trading range hypothesis yang diajukan Ikenberry et al. (1996) beranggapan bahwa perusahaan mengeluarkan saham bonus dengan harapan harga sahamnya akan turun di harga perdagangan yang optimal. Dan yang teori paling terkenal dalam menjelaskan motif saham bonus adalah signalling theory, dimana manajer perusahaan berusaha untuk mengurangi asymmetric information mengenai prospek perusahaan di masa mendatang dengan melakukan pembagian saham bonus seperti yang dijelaskan Grinblatt et al. (1984) dan McNichols \& Dravid (1990) dalam Campbell \& Ohuocha (2011).

Terdapat beberapa penelitian yang menguji volume perdagangan di sekitar pengumuman saham bonus. Pada penelitian yang dilakukan Malhotra et al. (2012) di Bombay Stock Exchange dan National Stock Exchange di India, disimpulkan bahwa terjadi penurunan pada trading volume di sekitar pengumuman saham bonus namun tidak signifikan. Penelitian yang dilakukan Masry (2015) di Egyptian Stock Exchange menemukan bahwa terdapat perbedaan abnormal trading volume yang signifikan di $t_{-13}: t_{+13}$. Ardiansyah (2002) menguji perbedaan volume perdagangan antara sebelum dan sesudah pengumuman saham bonus, hasilnya ia menemukan bahwa terdapat perbedaan yang signifikan. Hal yang sama juga disampaikan oleh Kurniawati (2007). Namun, Natasya \& Suganda (2013) berpendapat lain, dalam penelitiannya mereka menyimpulkan bahwa tidak terdapat perbedaan TVA yang signifikan antara sebelum dan sesudah pengumuman saham bonus.

Dari beberapa penelitian yang ada timbul research gap dan theory gap, yang membuat penulis tertarik untuk meneliti reaksi pasar terhadap pengumuman saham bonus dengan menggunakan ATVA. Selain itu dari penelitian yang sudah dilakukan untuk melihat reaksi pasar terhadap pengumuman saham bonus di Bursa Efek Indonesia, belum ada penelitian yang menggunakan ATVA untuk melihat reaksi pasarnya.

Penelitian ini merupakan expost facto research, dan berdasarkan tingkat eksplanasinya penelitian ini termasuk riset deskriptif dan komparatif. Namun, juga melakukan analisis TVA. Penelitian ini bertujuan mendeskripsikan ATVA pada perusahaan yang mengumumkan pembagian saham bonus, menganalisis reaksi pasar dan menganalisis perbedaan antara ATVA sebelum dan sesudah pengumuman saham bonus.

Ruang lingkup penelitian ini berfokus pada reaksi pasar pada pengumuman saham bonus di Bursa Efek Indonesia. Selain itu untuk menghindari bias, perusahaan yang melakukan corporate action lain selain saham bonus pada periode pengamatan tidak digunakan sebagai sampel.

Berdasarkan latar belakang dan tujuan penelitian maka hipotesis yang diajukan pada penelitian ini adalah terdapat reaksi pasar yang tercermin dari adanya ATVA yang signifikan di sekitar periode pengumuman saham bonus dan terdapat perbedaan ATVA yang signifikan antara sebelum dan sesudah pengumuman saham bonus. Reaksi pasar bisa tercermin dari adanya ATVA yang signifikan di sekitar pengumuman saham bonus. Umumnya reaksi akan timbul setelah adanya pengumuman saham bonus, namun tidak menutup kemungkinan terjadi sebelum pengumuman saham bonus. Hal ini karena adanya kebocoran informasi pada waktu sebelum pengumuman saham bonus.

\section{METODE PENELITIAN}

Pendekatan penelitian ini adalah kuantitatif (penelitian yang ditinjau dari sudut paradigma penelitian yang menekankan pada pengujian teori-teori melalui pengukuran variabel-variabel penelitian dengan angka dan melakukan analisa dengan data dan prosedur statistik). Berdasarkan tingkat pengendalian variabel 
bebasnya penelitian ini tergolong dalam expost facto research. Menurut Kerlinger (1976) dalam Umar (2009: 28) Penelitian expost facto merupakan pencarian empirik yang sistematik dimana peneliti tidak dapat mengontrol variabel bebasnya, karena peristiwa telah terjadi atau sifatnya tidak dapat dimanipulasi. Peristiwa pembagian saham bonus yang sudah terjadi dan tidak adanya manipulasi pada variabel bebas menjadikan penelitian ini tergolong expost facto.

Berdasarkan tingkat eksplanasinya penelitian ini termasuk riset deskriptif dan komparatif. Termasuk riset deskriptif karena penelitian ini berusaha menjawab rumusan masalah mengenai bagaimana deskripsi ATVA pada perusahaan yang mengumum-kan pembagian saham bonus. Selanjutnya berdasarkan rumusan masalah dan hipotesis yang bersifat komparatif dimana peneliti ingin mengetahui apakah terdapat reaksi pasar yang tercermin dari adanya ATVA yang signifikan di sekitar periode pengumuman saham bonus dan apakah terdapat perbedaan ATVA yang signifikan antara sebelum dan sesudah pengumuman saham bonus maka penelitian ini juga termasuk riset komparatif. Pengujian hipotesis pertama (H1) akan membandingkan ATVA pada periode jendela dengan ATVA normal. Disini akan dilakukan pengujian one sample test pada ATVA di periode jendela dengan angka 0 (nol). Hal ini karena nilai ATVA normal sama dengan TVA yang diekspektasikan investor. Oleh karena itu, 0 (nol) menggambarkan tidak adanya perbedaan antara ATVA dengan TVA yang diekspektasikan investor. Selanjutnya, pengujian hipotesis kedua (H2) dilakukan untuk membandingkan antara ATVA sebelum pengumuman saham bonus dengan sesudah pengumuman saham bonus. Disini akan dilakukan pengujian paired sample test antara ATVA sebelum pengumuman dan sesudah pengumuman.

Variabel bebas (independent variable) yang digunakan dalam penelitian ini adalah pengumuman pembagian saham bonus yang tanggalnya dinotasikan dalam bentuk $\mathrm{t}_{-5}, \mathrm{t}_{-4}, \mathrm{t}_{-3}, \mathrm{t}_{-2}, \mathrm{t}_{-1}, \mathrm{t}_{0}, \mathrm{t}_{+1}, \mathrm{t}_{+2}, \mathrm{t}_{+3}, \mathrm{t}_{+4}, \mathrm{t}_{+5}$ dan dikelompokkan menjadi sebelum dan sesudah pengumuman. Skala yang digunakan dalam mengukur variabel bebas adalah skala nominal. Sedangkan variabel terikat (dependent variable) dalam penelitian ini adalah ATVA dan skala yang digunakan adalah skala rasio.
Populasi penelitian ini adalah semua peristiwa pembagian saham bonus di BEI pada periode 1 Januari 2006 sampai dengan 31 Desember 2017. Data terakhir diperoleh 41 peristiwa pembagian saham bonus dari 1 Januari 2006 sampai dengan 31 Desember 2017. Penentuan sampel dalam penelitian ini dilakukan menggunakan metode non-probability sampling dengan teknik purposive sampling method. Kriteria yang ditetapkan antara lain tidak ada peristiwa corporate action yang bisa memengaruhi jumlah saham beredar selain saham bonus, misalnya melakukan dividen saham, right issue, waran, stock split, reverse split, merger dan akuisisi pada periode jendela. Besaran sampel yang digunakan dalam penelitian ini adalah sebesar 33 Peristiwa pembagian saham bonus. Untuk melihat rencana penelitian yang digunakan dalam penelitian ini dapat dilihat pada Gambar 1. Alat analisis data menggunakan statistik dengan alat berupa Statistical Product and Service Solutions (SPSS) versi 24 dan EViews 10. Ada dua macam statistik yang digunakan untuk analisis data yaitu statistik deskriptif dan statistik inferensial.

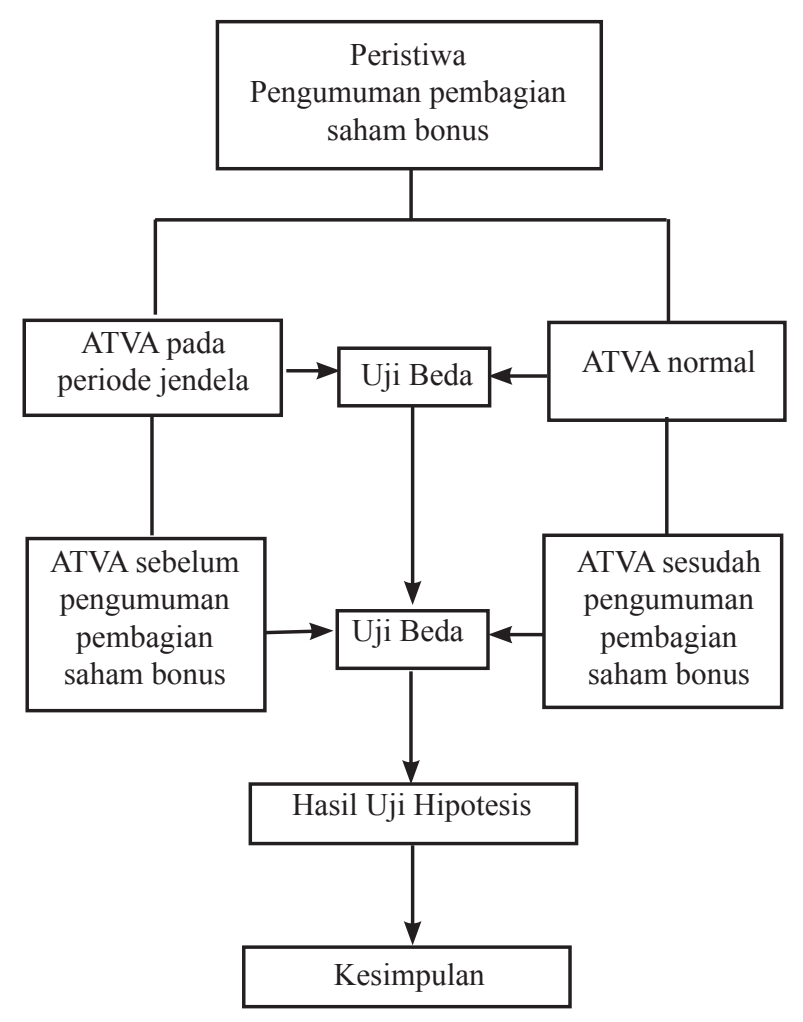

Gambar 1. Kerangka pemikiran penelitian 


\section{Model Perhitungan Data}

Karakteristik pasar modal Indonesia yang masih tergolong thin marketsesuai yang dinyatakan Kurniawati (2007) menjadikan penggunaan market model akan menimbulkan beta yang bias dan kurang sesuai jika digunakan. Oleh karena itu, model perhitungan ATVA yang digunakan dalam penelitian ini adalah mean adjusted model. Selain itu dari hasil penelitian Campbell \& Wasley (1996) dapat disimpulkan bahwa power dan sensitivitas mean-adjusted model tidak jauh berbeda dengan market model.

Dalam penelitian ini penulis menggunakan periode estimasi selama 120 hari perdagangan sebelum periode jendela. Periode jendela dalam penelitian ini menggunakan 11 hari, hal ini dimaksudkan untuk meminimalisasi adanya efek bias (confounding effect). Menurut Hartono (2012) lamanya periode jendela tergantung dari peristiwanya, jika peristiwa dapat dengan mudah ditentukan nilai ekonomisnya maka dapat menggunakan jendela yang pendek dan sebaliknya. Dalam penelitian ini penulis menggunakan 11 hari dengan asumsi bahwa 5 hari sebelum pengumuman saham bonus dapat digunakan untuk mengetahui adanya kebocoran informasi dan untuk melihat respon pasar sebelum informasi itu diumumkan. Sedangkan 5 hari sesudah pengumuman peristiwa dapat digunakan untuk mengetahui kecepatan respon pasar atas informasi dan hari ke-0 untuk mengetahui reaksi pasar pada tanggal pengumuman.

Untuk menghitung TVA digunakan rumus: TVA $_{\mathrm{i}, \mathrm{t}}=$ Volume Perdagangan ${ }_{\mathrm{i}, t} /$ Saham Beredar ${ }_{\mathrm{i}, \mathrm{t}}$. Dengan TVA $_{i, t}$ (TVA saham i pada waktu t). Penelitian ini menggunakan mean-adjusted model untuk mengetahui tingkat TVA yang diharapkan, yaitu dengan rumus:

$$
E\left[T V A_{i, t}\right]=\frac{1}{T} \sum_{j=t 1}^{t 2} T V A_{i, j}
$$

Keterangan: $\mathrm{E}_{\mathrm{TVA}} \mathrm{TV}_{\mathrm{i}, \mathrm{f}}$ (Expected TVA saham i pada waktu t); TVA $_{\mathrm{i}, \mathrm{j}}$ (TVA realisasi saham $\mathrm{i}$ di periode estimasi $\mathrm{j}$ ); $\mathrm{T}$ (Lamanya periode estimasi, yaitu dari waktu $t_{-1}$ sampai t2).

Perhitungan abnormal TVA untuk masing-masing saham emiten pada periode jendela adalah sebagai berikut.

$$
\mathrm{ATVA}_{\mathrm{i}, \mathrm{t}}=\mathrm{TVA}_{\mathrm{i}, \mathrm{t}}-\mathrm{E}\left[\mathrm{TVA}_{\mathrm{i}, \mathrm{t}}\right]
$$

Keterangan: ATVA $_{i, t}$ (Abnormal TVA saham i pada waktu t); E[TVA $_{\mathrm{i}, \mathrm{t}}$ (Expected TVA saham i pada waktu $\mathrm{t}) ; \mathrm{TVA}_{\mathrm{i}, \mathrm{t}}$ (TVA realisasi saham i pada waktu t). Setelah abnormal TVA masing-masing saham diketahui maka kemudian dihitung average abnormal TVA (AATVA).

$$
\operatorname{AATV}_{t}=\frac{1}{n} \sum_{i=1}^{n} A T V A_{i, t}
$$

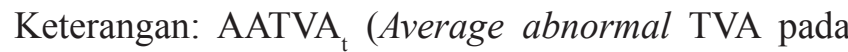
waktu t); ATVA $_{\mathrm{i}, \mathrm{t}}$ (Abnormal TVA saham i pada waktu t); $\mathrm{n}$ (Besaran sampel dalam pengamatan).

\section{Teknik Pengujian Hipotesis}

Langkah awal untuk melakukan analisis data dalam penelitian ini adalah uji statistik deskriptif. Uji statistik deskriptif digunakan untuk mendeskripsikan variabel dalam penelitian ini. Berikutnya dilakukan uji normalitas pada ATVA di sekitar periode pengumuman saham bonus. Dalam penelitian ini uji normalitas data akan menggunakan uji statistik Kolmogrov-smirnov.

Teknik analisis data yang digunakan untuk menguji $\mathrm{H} 1$ adalah uji statistik parametrik one sample t-test jika data berdistribusi normal, atau menggunakan uji statistik non parametrik one sample wilcoxon signed rank test jika data berdistribusi tidak normal. Pengujian $\mathrm{H} 2$ akan menggunakan uji statistik parametrik paired sample t-test jika data berdistribusi normal, atau menggunakan uji statistik non parametrik wilcoxon signed rank test jika data berdistribusi tidak normal.

\section{HASIL}

\section{Deskripsi ATVA Pada Perusahaan Yang Mengumumkan Pembagian Saham Bonus}

Objek penelitian dalam penelitian ini adalah ATVA di sekitar peristiwa pengumuman pembagian saham bonus pada periode 2008-2017 yang dilakukan oleh perusahaan yang terdaftar di Bursa Efek Indonesia. Dari data yang tersedia dapat diketahui bahwa terjadi 41 peristiwa pembagian saham bonus yang dilakukan oleh 33 perusahaan pada periode 2008-2017. Selanjutnya, sampel diseleksi berdasarkan kriteria yang sudah ditentukan, kriteria tersebut antara lain tidak adanya peristiwa corporate action yang bisa memengaruhi jumlah saham beredar selain saham bonus, dan datadata terkait emiten lengkap. Setelah melalui seleksi kriteria, 33 peristiwa pembagian saham bonus yang 
dibagikan oleh 28 perusahaan digunakan sebagai sampel dalam penelitian ini. Untuk melihat data terkait tanggal pengumuman saham bonus, kode emiten dan rasio yang dibagikan dapat dilihat pada Tabel 1 .

Tabel 1. Data pengumuman saham bonus yang menjadi sampel penelitian

\begin{tabular}{lccc}
\hline \multicolumn{1}{c}{ Security } & Tanggal & Exercise & Proceed \\
\multicolumn{1}{c}{ Pengumuman } & Ratio & Ratio \\
\hline BMTR & $22 / 06 / 2006$ & 1 & 1 \\
SMRA_1 & $27 / 06 / 2006$ & 5 & 2 \\
DPNS & $25 / 06 / 2007$ & 27 & 2 \\
AHAP & $29 / 06 / 2007$ & 52 & 10 \\
DART & $06 / 07 / 2007$ & 1 & 1 \\
PWON & $02 / 07 / 2008$ & 10 & 3 \\
ASRM_1 & $01 / 09 / 2008$ & 5 & 2 \\
MEGA & $26 / 05 / 2009$ & 70 & 67 \\
OKAS & $04 / 12 / 2009$ & 50 & 21 \\
BHIT & $16 / 04 / 2010$ & 1 & 3 \\
TOTL & $24 / 05 / 2010$ & 100 & 24 \\
KOIN & $21 / 07 / 2010$ & 100 & 15 \\
KREN & $06 / 01 / 2011$ & 25 & 1 \\
PEGE & $25 / 05 / 2011$ & 500 & 25 \\
EKAD & $31 / 05 / 2011$ & 4 & 1 \\
INVS_1 & $12 / 07 / 2011$ & 5 & 2 \\
BBLD & $01 / 05 / 2012$ & 500 & 73 \\
ASRM_2 & $29 / 05 / 2012$ & 7 & 2 \\
INDS_1 & $30 / 05 / 2012$ & 5 & 2 \\
GPRA & $03 / 07 / 2012$ & 3 & 1 \\
SMRA_2 & $10 / 06 / 2013$ & 1 & 1 \\
INVS_2 & $17 / 06 / 2013$ & 9 & 26 \\
SDMU & $20 / 06 / 2013$ & 4 & 1 \\
FAST & $21 / 06 / 2013$ & 3 & 10 \\
PADI_1 & $24 / 06 / 2013$ & 2 & 1 \\
NIPS & $30 / 09 / 2013$ & 10 & 8 \\
MYOR & $01 / 10 / 2013$ & 6 & 1 \\
TINS & $02 / 04 / 2014$ & 544 & 261 \\
PADI_2 & $23 / 05 / 2014$ & 10 & 3 \\
INDS_2 & $16 / 06 / 2014$ & 4 & 1 \\
SMMT & $19 / 06 / 2014$ & 2 & 5 \\
PSAB & $03 / 09 / 2014$ & 1 & 6 \\
BBYB & $21 / 04 / 2017$ & 10 & 1 \\
\hline & & & \\
\hline
\end{tabular}

Untuk mengetahui jumlah peristiwa pembagian saham bonus tiap tahunnya di BEI yang digunakan sebagai sampel dalam penelitian ini bisa dilihat pada Gambar 2. Pembagian saham bonus mengalami tren penurunan tiap tahunnya. Dari Gambar 2 dapat diketahui bahwa pada tahun 2006-2017 terjadi penurunan peristiwa pembagian saham bonus. Bahkan pada tahun 2015 dan 2016 tidak terjadi peristiwa pembagian saham bonus.

Penurunan jumlah peristiwa pembagian saham bonus bisa dijelaskan oleh beberapa alasan. Pertama, manajer perusahaan hanya akan membagikan saham bonus jika memang mereka yakin akan prospek perusahaan kedepannya seperti yang dijelaskan Grinblatt et al. (1984) dalam Campbell \& Ohuocha (2011). Tren penurunan jumlah peristiwa pembagian saham bonus terjadi karena perusahaan yang kurang yakin akan prospek kedepannya sehingga mereka menganggap tidak perlunya membagikan saham bonus dengan kondisi yang sedang mereka hadapi saat ini.

Kedua, karena likuiditas perdagangan saham perusahaan yang dianggap sudah mencukupi maka perusahaan berpikir tidak perlu membagikan saham bonus untuk meningkatkan likuiditas perdagangan saham. Dalam the liquidity hypothesis yang diungkapkan Lakonishok \& Lev (1987), menjelaskan perusahaan mengeluarkan saham bonus untuk meningkatkan trading volume dan likuiditas saham mereka dengan menambah jumlah saham yang beredar. Jika memang likuiditas perdagangan dianggap sudah mencukupi maka, perusahaan tidak akan mengeluarkan saham bonus.

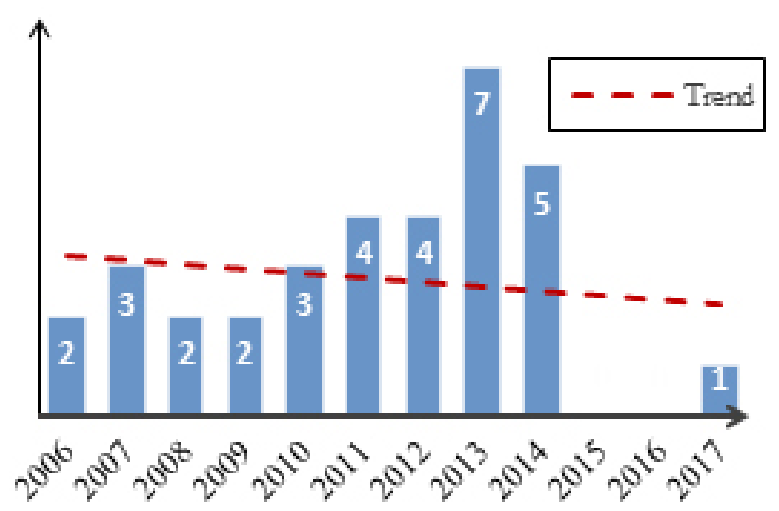

Gambar 2. Peristiwa pembagian saham bonus pada tahun 2006-2017 
Statistik deskriptif untuk ATVA selama periode jendela dalam penelitian ini dapat dijelaskan dengan Tabel 2 . Dapat dilihat nilai minimum, maximum, dan mean, ATVA di periode jendela. Statistik deskriptif untuk AATVA sebelum dan sesudah pengumuman saham bonus dapat dilihat pada Tabel 3 .

Penggunaan model perhitungan TVA yang tidak menggunakan transformasi log atau ln seperti yang dijelaskan Beaver (1986) dan Lo \& Wang (2000) memudahkankitauntuk membaca hasilATVA. Misalnya saja dapat diketahui bahwa nilai ATVA emiten PWON pada periode t-1 sebelum pengumuman saham bonus adalah sebesar 0,001977513 atau jika disederhanakan adalah sebesar 0,198\%. Angka ATVA sebesar 0,198\% menyiratkan bahwa terjadi rata-rata perdagangan yang tak normal sebesar $0,198 \%$ dari jumlah saham yang beredar. Jika diketahui jumlah saham yang beredar PT PAKUWON JATI Tbk adalah sebesar 7,7 miliar lembar saham, maka dapat disimpulkan bahwa pada sehari sebelum pengumuman saham bonus terjadi aktivitas perdagangan saham yang di luar ekspektasi investor sebesar 15 juta lembar saham pada emiten PWON. Untuk melihat rata-rata ATVA pada periode jendela saat perusahaan mengumumkan pembagian saham bonus dapat dilihat pada Gambar 3 .

Tabel 2. Statistik deskriptif ATVA pada periode jendela

\begin{tabular}{ccccc}
\hline Hari & $\mathrm{N}$ & Minimum & Maximum & Mean \\
\hline $\mathrm{t}-5$ & 33 & $-0,0109698$ & 0,0417541 & 0,0014239 \\
$\mathrm{t}-4$ & 33 & $-0,0109688$ & 0,0282164 & 0,0019494 \\
$\mathrm{t}-3$ & 33 & $-0,0106923$ & 0,0252190 & 0,0008508 \\
$\mathrm{t}-2$ & 33 & $-0,0109607$ & 0,0333725 & 0,0029681 \\
$\mathrm{t}-1$ & 33 & $-0,0109698$ & 0,0330057 & 0,0029365 \\
$\mathrm{t} 0$ & 33 & $-0,0147304$ & 0,0316668 & 0,0012966 \\
$\mathrm{t}+1$ & 33 & $-0,0164804$ & 0,0215455 & 0,0004336 \\
$\mathrm{t}+2$ & 33 & $-0,0109698$ & 0,0260157 & 0,0006108 \\
$\mathrm{t}+3$ & 33 & $-0,0170498$ & 0,0260042 & 0,0001530 \\
$\mathrm{t}+4$ & 33 & $-0,0121702$ & 0,0526908 & 0,0015749 \\
$\mathrm{t}+5$ & 33 & $-0,0121933$ & 0,0332353 & 0,0008613 \\
\hline
\end{tabular}

Tabel 3. Statistik deskriptif ATVA pada periode jendela

\begin{tabular}{ccccc}
\hline Periode & $\mathrm{N}$ & Minimum & Maximum & Mean \\
\hline Sebelum & 165 & $-0,0109698$ & 0,04175414 & 0,00202575 \\
Sesudah & 165 & $-0,0170498$ & 0,05269084 & 0,00072672 \\
\hline
\end{tabular}

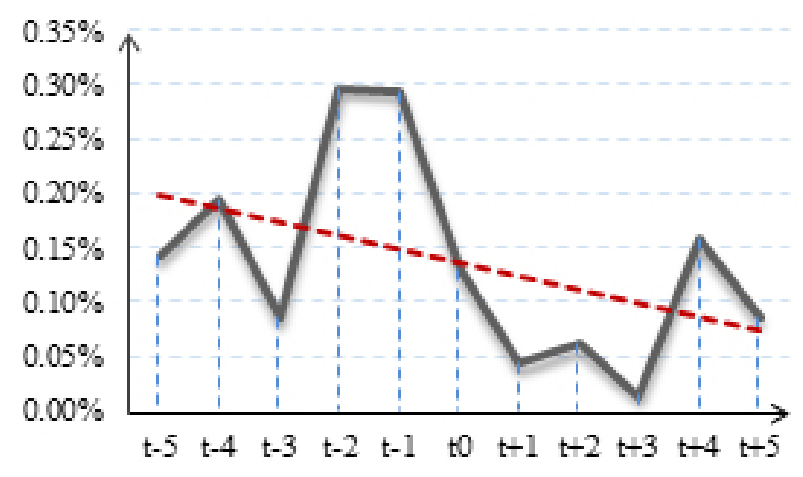

Gambar 3. AATVA pada periode jendela

Selanjutnya dilakukan uji normalitas dengan menggunakan uji statistik Kolmogrov-smirnov pada periode jendela. Berdasarkan Tabel 5 dapat diketahui bahwa data ATVA pada periode jendela berdistribusi tidak normal. Dari t-5 hingga t +5 tingkat signifikansi yang didapat di bawah 0,05 . Tingkat signifikansi di bawah 0,05 menandakan bahwa data berdistribusi tidak normal. Dari hasil pengujian normalitas diatas dapat disimpulkan bahwa pengujian hipotesis pertama (H1) akan menggunakan uji statistik non-parametrik one sample wilcoxon signed rank test.

Pengujian normalitas juga digunakan untuk melihat distribusi data ATVA sebelum dan sesudah pengumuman saham bonus. Pengujian ini bertujuan menentukan teknik analisis data yang akan digunakan untuk pengujian hipotesis kedua (H2), secara umum hasilnya dapat dilihat pada Tabel 6 .

Berdasarkan Tabel 6 dapat diketahui bahwa data ATVA pada sebelum dan sesudah pengumuman saham bonus memiliki tingkat signifikansi dibawah 0,05 . Tingkat signifikansi di bawah 0,05 menandakan bahwa data berdistribusi tidak normal. Dari hasil pengujian normalitas diatas dapat disimpulkan bahwa pengujian hipotesis kedua (H2) akan menggunakan uji statistik non parametrik wilcoxon signed rank test.

Model perhitungan TVA yang digunakan dalam penelitian ini juga mengakibatkan variabel ATVA yang diajukan memiliki distribusi data yang tidak normal. Karena asumsi dasar dari pengujian t-test yang biasa digunakan untuk menguji perbedaan adalah data berdistribusi normal maka solusi dari masalah distribusi yang tidak normal ini adalah menggunakan uji statistik non parametrik wilcoxon signed rank test. 
Pengujian kandungan informasi mengguna-kan uji statistik non parametrik dianggap memiliki power yang lebih baik dalam melihat adanya ATVA. Dalam penelitian yang dilakukan Campbell \& Wasley (1996) pada NYSE dan NASDAQ, mereka menyimpulkan bahwa uji statistik non parametrik lebih powerfull untuk mendeteksi adanya ATVA dibandingkan jika menggunakan uji statistik parametrik.. Selain itu uji statistik non parametrik juga tidak memerlukan asumsi distribusi data yang normal dalam pengujiannya.

\section{Reaksi Pasar terhadap Pengumuman Saham Bonus}

Pengujian terhadap hipotesis pertama (H1) dilakukan dengan menggunakan analisis statistik non-parametrik one sample wilcoxon signed rank test. Hasil pengujian ATVA pada periode jendela disajikan pada Tabel 7.

Berdasarkan pengujian hipotesis pertama (H1) ditemukan ATVA yang signifikan pada periode $\mathrm{t}-1$ sebelum pengumuman saham bonus, dengan nilai signifikansi sebesar 0,048. Dengan nilai signifikansi yang di bawah kriteria $(\alpha)$ sebesar $5 \%$, maka dapat disimpulkan bahwa $\mathrm{H} 1$ dalam penelitian ini diterima. Oleh karena itu, bisa ditarik kesimpulan bahwa pasar bereaksi terhadap pengumuman saham bonus.

ATVA yang signifikan di t-1 ini menandakan kemungkinan adanya kebocoran informasi terkait pembagian saham bonus. Informasi pembagian saham bonus merupakan informasi yang berharga terkait prospek perusahaan kedepannya, oleh karenanya kebocoran informasi terkait pembagian saham bonus akan segera dimanfaatkan oleh investor untuk mendapatkan keuntungan. Namun mengapa bisa sampai terjadi kebocoran informasi terkait pengumuman saham bonus?. Terdapat beberapa penjelasan mengapa hal ini bisa terjadi. Yang pertama adalah karena lemahnya manajemen informasi yang diberlakukan dan dipraktekkan pada suatu perusahaan. Indrajit (tanpa tahun) dalam artikelnya yang berjudul Fenomena Kebocoran Data, memberikan contoh tidak diberlakukannya aturan untuk mengenkripsi data atau informasi penting dan tergolong rahasia milik perusahaan akan mendorong terjadinya kebocoran informasi. Bukan tidak mungkin data terkait pengumuman pembagian saham bonus, berhasil dicuri baik oleh orang dalam maupun dari luar dan dimanfaatkan untuk mendapatkan keuntungan.
Tabel 5. Hasil uji normalitas ATVA di periode jendela

\begin{tabular}{cccc}
\hline \multirow{2}{*}{ Hari } & \multicolumn{3}{c}{ Kolmogorov-Smirnova } \\
\cline { 2 - 4 } & Statistic & $\mathrm{df}$ & Sig. \\
\hline $\mathrm{t}-5$ & 0,3568945 & 33 & 0,000 \\
$\mathrm{t}-4$ & 0,3173783 & 33 & 0,000 \\
$\mathrm{t}-3$ & 0,3012231 & 33 & 0,000 \\
$\mathrm{t}-2$ & 0,3884805 & 33 & 0,000 \\
$\mathrm{t}-1$ & 0,2736163 & 33 & 0,000 \\
$\mathrm{t} 0$ & 0,2814614 & 33 & 0,000 \\
$\mathrm{t}+1$ & 0,2597665 & 33 & 0,000 \\
$\mathrm{t}+2$ & 0,3118878 & 33 & 0,000 \\
$\mathrm{t}+3$ & 0,2607159 & 33 & 0,000 \\
$\mathrm{t}+4$ & 0,3679223 & 33 & 0,000 \\
$\mathrm{t}+5$ & 0,3408761 & 33 & 0,000 \\
\hline a) Lilliefors Significance Correction & &
\end{tabular}

Tabel 6. Uji normalitas ATVA sebelum dan sesudah pengumuman saham bonus

\begin{tabular}{lccc}
\hline \multirow{2}{*}{ Periode } & \multicolumn{3}{c}{ Kolmogorov-Smirnova ${ }^{\mathrm{a}}$} \\
\cline { 2 - 4 } & Statistic & $\mathrm{df}$ & Sig. \\
\hline Sebelum Pengumuman & 0,311 & 165 & 0,000 \\
Sesudah Pengumuman & 0,299 & 165 & 0,000 \\
\hline a) Lilliefors Significance Correction & & \\
\hline
\end{tabular}

Tabel 7. Hasil uji one sample wilcoxon signed rank test pada ATVA

\begin{tabular}{ccccc}
\hline Hari & AATVA & Z & Sig. & Keterangan \\
\hline t-5 & 0,00142 & $-0,384$ & 0,701 & Tidak Signifikan \\
t-4 & 0,00195 & 0,116 & 0,908 & Tidak Signifikan \\
t-3 & 0,00085 & 0,420 & 0,675 & Tidak Signifikan \\
t-2 & 0,00297 & 0,241 & 0,809 & Tidak Signifikan \\
t-1 & $\mathbf{0 , 0 0 2 9 4}$ & $\mathbf{1 , 9 7 4}$ & $\mathbf{0 , 0 4 8}$ & Signifikan \\
t0 & 0,00130 & 1,313 & 0,189 & Tidak Signifikan \\
t+1 & 0,00043 & $-0,045$ & 0,964 & Tidak Signifikan \\
t+2 & 0,00061 & $-1,010$ & 0,313 & Tidak Signifikan \\
t+3 & 0,00015 & 0,045 & 0,964 & Tidak Signifikan \\
t+4 & 0,00157 & 0,759 & 0,448 & Tidak Signifikan \\
t+5 & 0,00086 & $-0,402$ & 0,688 & Tidak Signifikan \\
\hline
\end{tabular}


Kedua, terkait faktor psikologis dari manusia itu sendiri yang ingin dianggap hebat oleh orang lain. Hal ini dijelaskan oleh Berger (2014) dalam bukunya yang berjudul Contagious, dimana manusia suka membocorkan rahasia dan berbagai informasi karena social currency. Social currency mengacu pada nilai yang dimiliki suatu informasi saat informasi tersebut dibagi antar invidu. Suatu informasi atau rahasia dianggap memiliki social currency yang baik jika orang ingin terus membagikannya pada orang lain.

Sama halnya dengan rahasia atau informasi yang lain, Informasi pengumuman saham bonus akan disebar pada kelompok-kelompok oleh orang-orang yang mengetahuinya terlebih dahulu. Alasannya sederhana, setiap orang ingin membuat orang lain terkesan dan mendapat pengakuan sosial. Ketika dianggap lebih hebat oleh orang lain, maka personal value orang tersebut naik. Sama seperti orang menggunakan uang untuk membeli produk atau jasa, kita menggunakan social currency untuk mendapatkan kesan positif yang diinginkan di antara keluarga, teman-teman, kerabat dan rekan kerja.

Ketiga terkait budaya orang Indonesia yang suka sekali membagi data atau informasi pada keluarga, kerabat, dan teman-temannya. Bahkan walaupun informasi yang disebarkan merupakan rahasia yang tidak boleh dibagikan, mereka tetap melakukannya karena beranggapan bahwa keluarga, kerabat dan temantemannya bisa menjaga rahasia tersebut. Namun, yang terjadi adalah sebaliknya, informasi yang diberikan diteruskan pada pihak pihak lain. Hingga pada akhirnya terdapat pihak tertentu yang mampu memanfaatkan informasi tersebut untuk keuntungan pribadinya.

Sebenarnya kandungan informasi apa yang dibawa pengumuman pembagian saham bonus, sehingga menyebabkan terjadinya reaksi pasar yang signifikan di t-1?. Menurut Grinblatt et al. (1984) dalam Campbell \& Ohuocha (2011) menyatakan pembagian saham bonus mengandung sinyal positif yang diungkapkan perusahaan karena perusahaan yakin akan prospek kedepannya. Namun, karena saat ini perusahaan sedang membutuhkan dana untuk investasi proyek yang akan dilakukan atau ketika perusahaan sedang dalam kesulitan dana maka saham bonus digunakan sebagai kompensasi atas penurunan dividen kas yang dibagikan saat ini.
Pembagian saham bonus juga bisa digunakan perusahaan untuk menarik perhatian dari para investor dan analis keuangan. Sesuai apa yang diungkapkan Grinblat et al. (1984) bahwa pengumuman pembagian saham bonus akan memicu para investor dan analisis keuangan untuk melakukan penilaian kembali terkait arus kas masa mendatang perusahaan. Hal inilah yang disebut Grinblatt et al. (1984) sebagai attention getting hypothesis, dimana pengumuman pembagian saham bonus bisa dilakukan perusahaan untuk menarik perhatian investor dan analis pasar modal. Namun apakah perusahaan bisa menggunakan pengumuman pembagian saham bonus sebagai false signal untuk menarik perhatian investor?. Hal ini bisa saja dilakukan oleh perusahaan, namun perusahaan akan lebih memilih tidak melakukannya. Karena ketika mereka menyampaikan false signal maka kemungkinan reputasi perusahaan akan menurun. Seperti yang disampaikan Heinkel (1984) dalam Grinblat et al. (1984) perusahaan berusaha menjaga reputasi dengan harapan bahwa di masa mendatang perusahaan bisa menyampaikan sinyal yang dikehendaki dengan baik dan pasar meresponnya sesuai sinyal yang disampaikan.

Memang benar bahwa pasar bereaksi pada pengumuman saham bonus, tetapi kita tidak bisa menyimpulkan apakah reaksinya positif atau tidak. Disinilah letak kelemahan dari pengujian kandungan informasi menggunakan volume perdagangan yang tidak mampu menyimpulkan reaksi positif atau tidak, walaupun mempunyai kelebihan dalam hal sensitifitasnya.

Hasil pengujian dalam penelitian ini berbeda dengan apa yang dikemukakan Malhotra et al. (2012). Dalam penelitiannya pada peristiwa pengumuman saham bonus di Bombay Stock Exchange dan National Stock Exchange di India, mereka menyimpulkan bahwa terjadi penurunan pada trading volume di sekitar pengumuman saham bonus namun tidak signifikan.

\section{Perbedaan ATVA Sebelum dan Sesudah Pengumuman Saham Bonus}

Pengujian Hipotesis Kedua (H2) dilakukan menggunakan uji statistik non parametrik wilcoxon signed rank test. Hasil uji wilcoxon signed rank test pada sebelum dan sesudah pengumuman saham bonus disajikan pada Tabel 8. 
Tabel 8. Hasil uji wilcoxon signed rank test pada ATVA

\begin{tabular}{lccc}
\hline Keseluruhan Sampel & $\mathrm{N}$ & Mean Rank & Sum of Ranks \\
\hline Negative Ranks & $87^{\mathrm{a}}$ & 78,21 & 6804,00 \\
Positive Ranks & $65^{\mathrm{b}}$ & 74,22 & 4824,00 \\
Ties & $13^{\mathrm{c}}$ & & \\
\hline Total & 165 & $-1,821 \mathrm{~d}$ \\
\hline \multicolumn{3}{c}{ Z } & 0,069 \\
\hline \multicolumn{3}{c}{ Asymp. Sig. (2-tailed) }
\end{tabular}

Keterangan: a (Sesudah Pengumuman Saham Bonus $<$ Sebelum Pengumuman Saham Bonus); b (Sesudah Pengumuman Saham Bonus $>$ Sebelum Pengumuman Saham Bonus), c (Sesudah Pengumuman Saham Bonus = Sebelum Pengumuman Saham Bonus); d (Based on positive ranks).

Berdasarkan Tabel 8 dapat dilihat bahwa nilai $\mathrm{Z}$ adalah sebesar -1,821 dengan nilai signifikansi sebesar 0,069. Hasil pengujian ini menunjukkan bahwa tidak terdapat perbedaan ATVA antara periode sebelum dan sesudah pengumuman saham bonus pada tingkat signifikansi ( $\alpha$ ) 5\%, namun hasil menjadi signifikan ketika tingkat signifikansi penelitian adalah $10 \%$. Oleh karena itu, bisa disimpulkan bahwa terdapat perbedaan ATVA yang signifikan antara sebelum dan sesudah pengumuman saham bonus. Dimana nilai ATVA pada periode sesudah pengumuman saham bonus lebih rendah dari pada sebelum pengumuman saham bonus.

Adanya suatu informasi baru yang muncul di pasar modal akan mendorong terjadinyaaktivitas perdagangan saham. Hal ini karena ketika suatu informasi baru muncul, investor dengan segera menganalisa apakah informasi tersebut mempunyai kandungan informasi (information content) atau tidak didalamnya. Selanjutnya ketika mereka menganggap bahwa informasi tersebut memiliki kandungan informasi (information content) maka mereka akan melakukan penilaian kembali terhadap saham yang terdampak dari adanya informasi tersebut (Karpoff, 1986). Apakah dengan adanya informasi baru ini saham tersebut sekarang menjadi undervalued atau overvalued.

Penurunan nilai ATVA pada periode sesudah pengumuman saham bonus terjadi karena strategi investor. Dimana ketika terjadi kebocoran informasi terkait pengumuman saham bonus pada $\mathrm{t}-1$ sesuai dengan hasil pada pengujian reaksi pasar, investor mencoba untuk membeli dan selanjutnya menahan sementara sahamnya sampai pada periode cum date berakhir. Strategi ini dilakukan investor karena menurut peraturan investor harus memiliki saham hingga cum date berakhir supaya memperoleh jatah dari pembagian saham bonus. Namun, setelah cum date berakhir bisa jadi investor segera menjual kembali sahamnya. Praktek inilah yang mendorong turunnya harga saham pada umumnya setelah cum date seperti yang diungkapkan Samsul (2015).

Motif perusahaan melakukan pembagian saham bonus selain sebagai kompensasi atas menurunnya dividen kas yang dibagikan adalah karena perusahaan menilai perlunya meningkatkan modal disetor. Dengan bertambahnya modal disetor maka kepercayaan dari pihak ketiga terhadap perusahaan semakin besar (Samsul, 2015).

Hasil temuan dalam penelitian ini sama dengan hasil yang diperoleh dari penelitian yang dilakukan oleh Ardiansyah (2002), Kurniawati (2007) dan Masry (2015). Dalam penelitiannya mereka menyimpulkan bahwa terdapat perbedaan yang signifikan pada volume perdagangan sebelum dan sesudah pengumuman saham bonus. Namun, hasil penelitian ini berbeda dengan apa yang diungkapkan Natasya dan Suganda (2013), yaitu tidak terdapat perbedaan TVA yang signifikan antara sebelum dan sesudah pengumuman saham bonus.

\section{Implikasi Manajerial}

hasil analisis yang sudah dilakukan terbukti bahwa pengumuman saham bonus berdampak pada aktivitas perdagangan saham. Hal ini perlu diperhatikan perusahaan dan manajer sebagai pengambil keputusan, dimana kebijakan untuk melakukan pembagian saham bonus akan segera direspon oleh pasar. Manajer perlu mewaspadai terkait bocornya informasi terkait pengumuman pembagian saham bonus, karena tidak sedikitinformasi seperti inibisa dimanfaatkan oleh pihakpihak yang tidak bertanggung jawab untuk memperoleh keuntungan. Disini perusahaan perlu menerap-kan sistem informasi yang baik untuk mencegah kebocorankebocoran informasi terjadi. Kebocoran informasi bisa merugikan perusahaan secara langsung terkait citra perusahaan yang tidak mampu mengelola informasi yang beredar. Selain itu perusahaan perlu mewaspadai aktivitas perdagangan sahamnya yang menurun setelah pengumuman saham bonus. Hal ini bisa terjadi karena adanya kebocoran informasi terkait pengumuman saham bonus. Jika perusahaan mampu mencegah terjadinya kebocoran informasi ini maka pasar akan bereaksi setelah pengumuman saham bonus bukan sebaliknya. 
Terkait motif perusahaan untuk mengeluar-kan saham bonus sebaiknya perusahaan menghindari mengeluarkan saham bonus hanya untuk mendapatkan perhatian dari para investor dan analis keuangan. Perusahaan dalam mengeluarkan saham bonus perlu memperhati-kan likuiditas perdagangan saham dan harga sahamnya saat ini, apakah memang perlu membagikan saham bonus atau tidak. Dan juga perusahaan sebelum mengeluarkan saham bonus perlu memperhatikan prospek perusahaan kedepannya.

Analisis ATVA lebih sensitif untuk mendeteksi reaksi pasar terkait suatu peristiwa yang terjadi. Namun, analisis ATVA belum bisa menentukan apakah reaksi pasar tersebut positif atau negatif. Disini bisa digunakan dua pendekatan analisa untuk melihat reaksi pasar pada suatu peristiwa, yaitu analisis abnormal return dan analisa ATVA sehingga bisa memperoleh informasi yang lebih mendalam

\section{KESIMPULAN DAN SARAN}

\section{Kesimpulan}

Hasil analisis data dan pembahasan yang sudah dipaparkan di atas maka kesimpulan dalam penelitian ini adalah terjadi kecenderungan penurunan jumlah peristiwa pembagian saham bonus tiap tahunnya. Hal ini disebabkan karena perusahaan menganggap tidak perlu membagikan saham bonusnya untuk saat tertentu. Dimana saat perusahaan kurang yakin akan prospek perusahaan kedepannya dan likuiditas perdagangan sahamnya dianggap masih mencukupi maka perusahaan akan menahan diri untuk mengeluarkan saham bonus. Pasar bereaksi pada pengumuman pembagian saham bonus, hal ini ditandai dengan adanya ATVA yang signifikan di t-1. Reaksi ini timbul dari adanya kebocoran informasi mengenai pembagian saham bonus. Kebocoran ini bisa terjadi karena manajemen informasi yang kurang baik, faktor psikologi, dan budaya Indonesia. Terdapat perbedaan ATVA yang signifikan antara sebelum dan sesudah pengumuman saham bonus. Pada periode sesudah pengumuman saham bonus nilai ATVA lebih rendah dari pada periode sebelum pengumuman saham bonus. Penurunan ATVA ini terjadi karena strategi investor untuk menahan saham yang sudah dimiliki sampai periode cum date berakhir.

\section{Saran}

Bagi perusahaan sebaiknya perlu mempertimbangkan lagi dampak pembagian saham bonus ini pada nilai perusahaan yang dipersepsikan investor. Hal ini karena investor memiliki pandangan yang berbeda terkait pembagian saham bonus. Jika perlu perusahaan seharusnya memberikan alasan atau motif mengapa mereka melakukan pembagian saham bonus.

Bagi investor dan calon investor sebaiknya mempertimbangkan menggunakan juga volume perdagangan sebagai analisis teknikal dalam melakukan perdagangan saham mengingat pentingnya informasi yang dikandung volume perdagangan. Selain itu, investor perlu mewaspadai adanya aktivitas perdagangan saham yang tak normal karena kemungkinan adanya informasi baru yang akan dipublikasikan. Selanjutnya investor sebaiknya mencermati sinyal yang diberikan perusahaan terkait pembagian saham bonus, jangan hanya tergiur untuk mendapatkan saham bonus.

Bagi peneliti selanjutnya sebaiknya meneliti peristiwaperistiwa lain seperti pembagian dividen, right issue, waran, dan yang lainnya dengan menggunakan metode pengujian kandungan informasi berbasis volume perdagangan. Selain itu, sebaiknya peneliti selanjutnya menggunakan model estimasi lain seperti market model dan EGLS model untuk menghitung ATVA.

\section{DAFTAR PUSTAKA}

Ahsan AFMM, Chowdhury MAR, Sarkar AH. 2014. An empirical study on market reaction around the bonus issues announcements in Bangladesh. International Journal of Economics and Finance $6(1): 82-98$

Ardiansyah. 2002. Pengaruh pengumuman saham bonus terhadap volume perdagangan saham. Media Riset Akuntansi, Auditing, dan Informasi 2(2): $1-26$

Ardiansyah F. 2012. Analisis reaksi pengumuman saham bonus terhadap return dan abnormal return di Bursa Efek Indonesia 2000-2012. Jurnal Ilmiah Mahasiswa FEB 1(2).

Baker HK \& Kapoor S. 2015. Why Indian firms issue stock distributions. Managerial Finance 41(7):658-672. https://doi.org/10.1108/MF-082014-0213. 
Beaver WH. 1968. The information content of annual earnings announcements. Journal of Accounting Research 6(1): 67-92. https://doi. org/10.2307/2490070.

Berger J. 2014. Contagious: Rahasia Di Balik Produk

\& Gagasan Yang Populer. Jakarta: Gramedia Pustaka Utama

Blume L, Easley D, O'Hara M. 1994. Market statistics and technical analysis: the role of volume. Journal of Finance 49(1): 153-181. https://doi. org/10.1111/j.1540-6261.1994.tb04424.x.

Campbell CJ, Wasley CE. 1996. Measuring abnormal daily trading volume for samples of NYSE/ ASE and NASDAQ securities using parametric and nonparametric test statistics. Review of Quantitative Finance and Accounting 6(1): 309326. https://doi.org/10.1007/BF00245187.

CampbellK, OhuochaC. 2011. Thestockmarketreaction to stock dividends in Nigeria and their information content. Managerial Finance 37(3):295-311. https://doi.org/10.1108/03074351111113333.

Conrad JS, Hameed A, Niden C. 1994. Volume and autocovariances in short-horizon individual security returns. The Journal of Finance 49(4):1305-1329.https://doi.org/10.1111/ j.1540-6261.1994.tb02455.x.

Dewi NPR, Sukartha IM. 2015. Reaksi pasar terhadap pengumuman saham bonus di bursa efek Indonesia. E-jurnal Akuntansi Universitas Udayana 10(1): 150-163.

Fama E. 1970. Efficient capital markets: a review of theory and empirical work. The Journal of Finance 25(2): 383-417. https://doi. org/10.2307/2325486.

Fernando KGK, Guneratne PSM. 2009. Measuring Abnormal Performance in Event Studies: An Application with Bonus Issue Announcements in Colombo Stock Exchange (CSE). SSRN: https:// ssrn.com/abstract $=1513320$ or http://dx.doi. org/10.2139/ssrn. 1513320 .

Grinblatt MS, Masulis RW, Titman S. 1984. The valuation effects of stock splits and stock dividends. Journal of Financial Economics 13(4): 461-490. https://doi.org/10.1016/0304405X(84)90011-4.

Hartono J. 2012. Pasar Efisien secara Informasi, Operasional, dan Keputusan. Yogyakarta: BPFE UGM.

Heinkel R. 1984. A theory of credibility: Costless signals in a rational expectations, infinite horizon model. Working paper.
Ikenberry DL, Rankine G, Stice EK. 1996. What do stock splits really signal?. The Journal of Financial and Quantitative Analysis 31(3): 357375. https://doi.org/10.2307/2331396.

Indrajit RE. Tanpa Tahun. Fenomena Kebocoran Data: Mencari Sumber Penyebab dan Akar Permasalahannya. Indonesia Security Incident Response Team on Internet and Infrastructure. (Online) (https://idsirtii.or.id/doc/IDSIRTIIArtikel309-FenomenaKebocoranData.pdf).

Kerlinger FN. 1976. Foundations of Behavioral Research (2nd edition). New York: Holt, Rinehart \& Winston.

Khurana R, Warne DP. 2016. Stock price adjustments to selected corporate announcements: a study of bonus issue announcements. International Journal of Innovations in Engineering and Technology 7(4): 253-259.

Kurniawati I. 2007. Pola pergerakan harga saham dan tingkat likuiditas saham pada pengumuman bonusshare. Jurnal Akuntansi dan Auditing Indonesia 11(2): 173-186

Lakonishok J, Lev B. 1987. Stock splits and stock dividends: why, who and when. The Journal of Finance 42(4): 913-932. https://doi.org/10.1111/ j.1540-6261.1987.tb03919.x.

Malhotra MM, Themozhi M, Gopalaswamy AK. 2012. Liquidity changes around bonus and rights issue announcements: Evidence from manufacturing and service sectors in India. International Journal of Money, Banking, and Finance 1(1): 28-34.

Masry M. 2015. The impact of the announcement of distribution bonus shares on abnormal returns and trading volume in the egyptian stock market. The International Journal of Social Sciences and Humanities Invention 2(12): 1717-1731. https:// doi.org/10.18535/ijsshi/v2i12.02.

McNichols M, Dravid A. 1990. Stock dividends, stock splits, and signalling. The Journal of Finance 45(3): 857-879. https://doi.org/10.1111/j.15406261.1990.tb05109.x.

Natasya LA, Suganda TR. 2013. Kandungan informasi pengumuman saham bonus: studi empiris di bursa efek Indonesia. Jurnal Keuangan dan Perbankan 17(3): 389-399.

Ndegwa JN, Kiweu JM. 2013. Is There profit from bonus share announcements in nairobi securities exchange?. Research Journal of Finance and Accounting 4(8): 10-18. 
Raja M, Sudhahar JC. 2010. An empirical test of indian stock market efficiency in respect of bonus announcement. Asia Pacific Journal of Finance and Banking Research 4(4): 1-14.

Rohit B, Pinto P, Shakila B. 2013. Market reaction to bonus announcements: empirical evidence from bombay stock exchange. Adarsh Journal of
Management Research 6(1): 28-38. https://doi. org/10.21095/ajmr/2013/v6/i1/88336.

Samsul M. 2015. Pasar Modal dan Manajemen Portofolio. Jakarta: Penerbit Erlangga.

Umar H. 2009. Metode Penelitian Untuk Skripsi dan Tesis Bisnis Edisi Kedua. Jakarta: PT Raja Grafindo Persada. 